\title{
Factitious Diabetes and Antibody Mediated Resistance to Beef Insulin
}

\author{
A. B. Kurtz, M. G. Harrington, J. A. Matthews, and J. D. N. Nabarro \\ Cobbold Laboratories and Department of Nuclear Medicine, The Thorn Institute of Clinical Science, \\ The Middlesex Hospital Medical School, London, England
}

Summary. A case of factitious diabetes is reported. The patient gave herself insulin intermittently over a four year period. A high concentration of insulin binding antibody was found with the antibody showing much greater avidity towards beef than human insulin. There was resistance to intravenously administered beef insulin with low concentrations of free insulin and high concentrations of bound insulin. In contrast, in response to a glucose tolerance test, both the free insulin and C-peptide responses were normal as was glucose tolerance. The clinical difference in responsiveness to the human and beef insulins is well illustrated in vitro by insulin binding differences and is probably a function not only of different equilibrium constants of the antibody for human and beef insulins but also of different high affinity binding site concentrations.

Key words: Factitious diabetes, insulin resistance, insulin-binding antibodies.

In many insulin requiring diabetics some endogenous insulin secretion continues and this may help to improve diabetic control $[1,2]$. It is not known to what extent the antibodies formed to the exogenous beef or pork insulin interfere with the endogenous insulin. The insulin binding antibodies of non-diabetic patients are of considerable interest as their effect on endogenous insulin secretion can be studied. In 1956 Berson et al. [3] reported insulin antibodies in insulin-shock treated schizophrenic subjects who were not diabetic. Recently several patients with hypoglycaemia have been found to have insulin binding antibodies without a history of insulin therapy [4-6]. It appears that these autoantibodies can cause glucose intolerance during glucose loading with subsequent hypoglycaemia when the antibody bound insulin maintains an inappropriately high free insulin concentration [6]. We describe a non-diabetic patient who had factitious hyperglycaemia and glycosuria and who took insulin intermittently over four years.

\section{Case Report}

A twenty-eight year old nurse was first admitted to this hospital in 1975 with polydipsia and polyuria. There was no family history of diabetes and she was of normal weight. Records from another hospital showed an eight year history of episodic left loin pain: no diagnosis had been made in spite of extensive investigations including laparotomy. Five years before admission low dose prednisolone was given for idiopathic hirsutism and was continued for four years. In 1974 glycosuria and a blood glucose of $14.9 \mathrm{mmol} / 1$ were found. Subsequent hospital investigations, including three normal glucose tolerance tests, led to the conclusion that the patient did not have diabetes. She gave herself insulin anyway and in retrospect had been doing so for some time.

At the time of admission to this hospital blood glucose was $11.1 \mathrm{mmol} / \mathrm{l}$, the urine was free of glucose and routine biochemical tests showed a plasma potassium concentration of $2.5 \mathrm{mmol} / \mathrm{l}$. Intravenous fluids and potassium supplements were given without insulin with rapid improvement. After discharge the patient recommenced insulin ( 26 units of beef/pork lente insulin daily). A further glucose tolerance test was performed as an out-patient; the fasting glucose was $14.7 \mathrm{mmol} / 1$, the 1 hour concentration $16.3 \mathrm{mmol} / 1$ and the 2 hour concentration $16.2 \mathrm{mmol} / \mathrm{l}$. It was thought that this was genuine and the patient continued on insulin with follow-up at the diabetic clinic.

Two years later reported haematuria and abdominal pain led to re-admission. No urinary abnormality was found. Discordance between high finger-prick blood glucose concentrations and low venous blood glucose concentrations was noted and a supply of glucose solution was found in a contact lens solution bottle. The patient admitted adding glucose to urine and putting glucose on her fingers before finger-prick sampling. Of greater interest was the admission that the glucose tolerance test two years before followed self-administration of prednisolone and glucose. She also admitted taking glucagon injections on occasions before clinic visits. After discussion with the patient insulin was discontinued and 


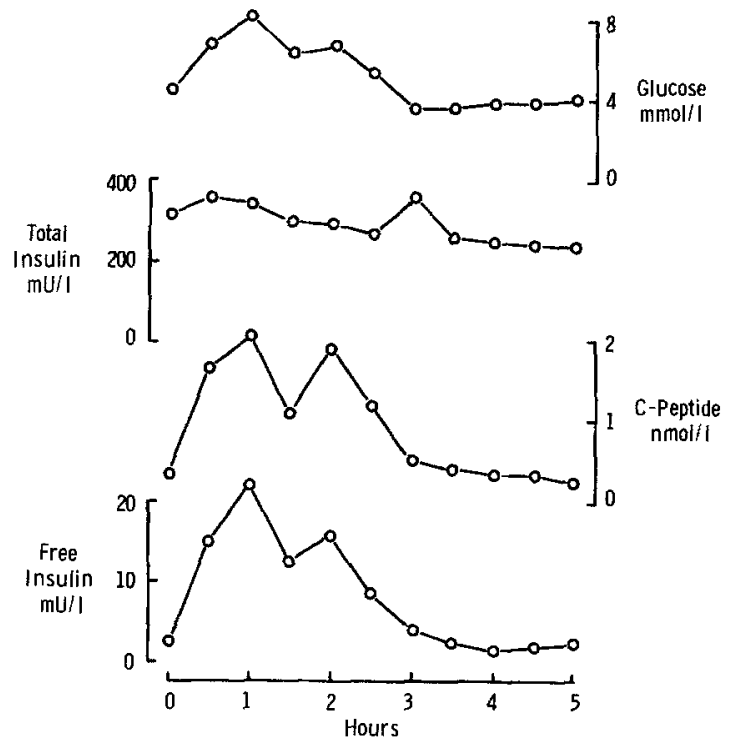

Fig. 1. Oral glucose tolerance test ( $50 \mathrm{~g}$ glucose)

Table 1. In-vitro studies of insulin-binding antibody using labelled beef, pork and human insulins. In the serum sample studied the total insulin was $170 \mathrm{mU} / 1$ and the free insulin $5 \mathrm{mU} / \mathrm{l}$. The equilibrium constants and antibody binding site concentrations are for the high affinity binding sites

\begin{tabular}{lcll}
\hline & Bovine & Porcine & Human \\
\hline $\begin{array}{l}\text { Binding of labelled } \\
\text { insulin: per cent bound }\end{array}$ & 90 & 59 & 41 \\
$\begin{array}{l}\text { Bound/Free } \\
\begin{array}{l}\text { Insulin binding } \\
\text { capacity: mU/1 }\end{array}\end{array}$ & 9 & 1.4 & 0.7 \\
$\begin{array}{l}\text { Association rate } \\
\text { per cent/min }\end{array}$ & 79 & 90 & 40 \\
$\begin{array}{l}\text { Dissociation rate } \\
\text { constant: min }{ }^{-1}\end{array}$ & 0.099 & 0.082 & 0.19 \\
$\quad \begin{array}{l}\text { k-1 } \\
\text { k-2 }\end{array}$ & 0.0039 & 0.0048 & 0.0045 \\
$\begin{array}{l}\text { Equilibrium constant } \\
\text { K: } 1 / \text { mol }\end{array}$ & $9.2 \times 10^{8}$ & $6.2 \times 10^{8}$ & $3.2 \times 10^{8}$ \\
$\begin{array}{l}\text { Antibody binding site } \\
\text { concentration Q: } U / L\end{array}$ & 4.8 & 2.4 & 1.8 \\
\hline
\end{tabular}

serial blood glucose concentrations were all normal. A moderately high concentration of insulin binding antibody was found and readmission arranged for a further oral glucose tolerance test and an intravenous insulin test.

\section{Methods}

Human, pork and beef insulins (kindly provided by Novo Laboratories $\mathrm{Ltd}$.) were iodinated with ${ }^{125} \mathrm{I}$ using lactoperoxidase [7] and purified on cellulose columns [8]. The specific activity was $30-50 \mu \mathrm{Ci} / \mu \mathrm{g}$.

Free and total insulin concentrations were assayed by the method of Nakagawa [9]. Binding of labelled insulin and association and dissociation rates were determined by established methods [10]. 'Insulin binding capacity' was determined by a mod-

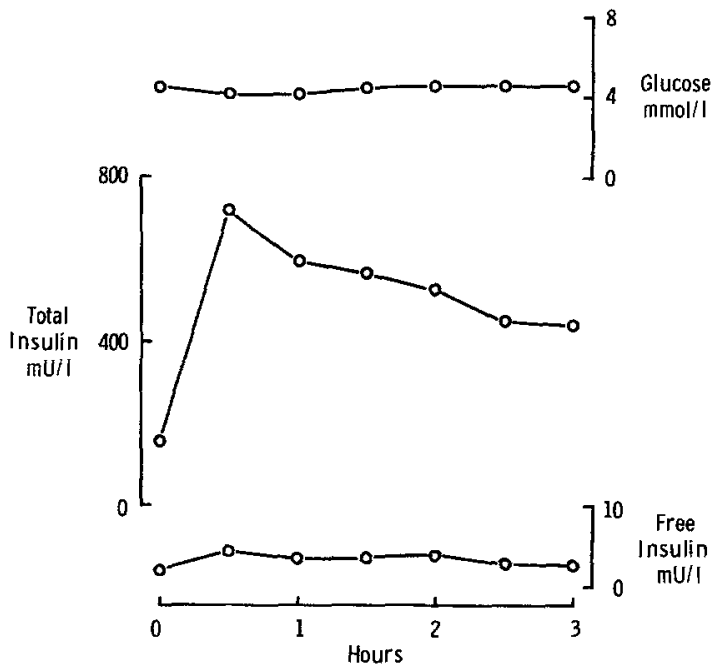

Fig. 2. Intravenous beef-insulin test $(0.15 \mathrm{U} / \mathrm{kg}$, dose $=8 \mathrm{U})$

ification of Andersen's method [11]. C-peptide was assayed as described by Heding et al. [12] with modifications suggested by Kuzuya et al. [13] (reagents provided by Novo Laboratories Ltd.). Equilibrium constants and antibody binding site concentration were determined by Scatchard analysis.

\section{Results}

The response to $50 \mathrm{~g}$ oral glucose is shown in Figure 1. Diabetes is excluded by the normal glucose curve and by the normal C-peptide response [12]. There was a good free insulin response with very little change in total insulin concentration. By contrast there was insulin resistance after intravenous injection of beef insulin $(0.15 \mathrm{U} / \mathrm{kg}$, weight $54 \mathrm{~kg})$; there was virtually no free insulin response and no hypoglycaemia (Fig. 2). Virtually all of the insulin appeared in the total (i. e. bound) fraction and was slowly removed with a half-life of 220 minutes.

In vitro antibody studies showed more avid binding of beef than human insulin; pork insulin was intermediate (Table 1).

\section{Discussion}

Factitious diabetes can present a difficult problem. This case report illustrates a number of ways in which a patient can manipulate laboratory tests. These range from the addition of glucose to urine and capillary blood samples to the alteration of carbohydrate tolerance by taking steroids, glucagon or glucose loading. Our exclusion of a diagnosis of diabetes in this situation was based on the history and on a nor- 
mal glucose tolerance test carried out under carefully controlled conditions with measurement of free insulin and C-peptide. C-peptide provides a useful marker of endogenous insulin secretion in the presence of insulin binding antibodies and in this patient free insulin concentrations paralleled C-peptide concentrations during the glucose tolerance test. Insulin abuse more commonly presents as hypoglycaemia. Scarlett et al. [14] in a recent report on factitious hypoglycaemia include a similar patient (Case 6) who appears to have factitious diabetes as a variant of the Munchausen syndrome.

Lowell in 1942 [15] described a patient with insulin treated diabetes who developed insulin binding antibodies which caused insulin resistance to beef/ pork insulin but not to injected human insulin. The patient we describe has similar antibodies which cause resistance to beef insulin but not to endogenous insulin. Goldman et al. [4] described five patients with spontaneous insulin binding antibodies in whom in vitro antibody studies showed equally avid binding of human and beef insulins. It seems that in the autoimmune syndrome the antigenic stimulus is human insulin and the antibodies that are formed react equally with human, beef and pork insulins. In contrast, in this patient, the antigen is injected beef/pork insulin and the antibodies show marked species differences.

The antibodies formed in our patient after four years of intermittent beef/pork insulin injection show marked in vivo reaction differences between exogenous beef insulin and endogenous insulin and in-vitro studies confirm this difference. The various methods used all have limitations [10]. As insulin from any species (beef, pork, human) displaces any labelled insulin completely we conclude, as did Berson and Yalow [16], that the actual total number of insulin binding sites is the same for each insulin species with variation of affinity contributing to the different results. In our patient the antibodies have fewer high affinity binding sites for human than for beef insulin and their affinity is also less. The clinical effect of antibody could well be a product of antibody capacity (Q) and affinity (K). The ratio of bound to free hormone $(\mathrm{B} / \mathrm{F})$ is proportional to $\mathrm{KQ}$ when most of the binding sites are free, which is the usual case clinically. Antibody avidity is probably best represented by $\mathrm{KQ}$ and in the absence of individual measurements of $K$ and $Q$ the value $B / F$ is theoretically meaningful and easy to measure. From a practical point of view the percent binding and the $\mathrm{B} / \mathrm{F}$ ratio with different species of insulin are as good clinical indicators as the more complicated in-vitro tests: the best way of showing how antibodies affect insulin action must be with in-vivo tests with measurement of free and total insulin fractions.
Acknowledgements. This work was undertaken with the aid of a grant from Nordisk Insulinlaboratorium.

\section{References}

1. Faber, O. K., Binder, C.: B-cell function and blood glucose control in insulin dependent diabetics within the first month of insulin treatment. Diabetologia 13, 263-268 (1977)

2. Reynolds, C., Molnar, G. D., Horwitz, D. L., Rubenstein, A. H., Taylor, W. F., Jiang, N. S.: Abnormalities of endogenous glucagon and insulin in unstable diabetes. Diabetes 26 36-45 (1977)

3. Berson, S. A., Yalow, R. S., Bauman, A., Rothschild, M. A., Newerly, K.: Insulin $\mathbf{I}^{131}$ metabolism in human subjects. Demonstration of insulin binding globulin in circulation of insulin treated subjects. J. Clin. Invest. 35, 170-190 (1956)

4. Goldman, J., Baldwin, D., Klink, D., Blackard, W. G., Fisher, L., Schnure, J., Rubenstein, A. H.: Insulin and proinsulin antibodies in autoimmune hypoglycaemia. Clin. Res. 25, 391A (1977)

5. Hirata, Y.: Spontaneous insulin antibodies and hypoglycaemia, In: Diabetes. Bajaj, J. S., (Ed.), pp. 278-284. Amsterdam: Excerpta Medica 1977

6. Ichihara, K., Shima, K., Saito, Y., Nonaka, K., Tarui, S. Nishikawa, M.: Mechanism of hypoglycaemia observed in a patient with insulin autoimmune syndrome. Diabetes $\mathbf{2 6}$, 500-506 (1977)

7. Karonen, S.-L., Mörsky, P., Siren, M., Seuderling, U.: An enzymatic solid phase method for trace iodination of proteins and peptides with ${ }^{125}$ Iodine. Anal. Biochem. 67, 1-10 (1975)

8. Gavin, J. R., Roth, J., Jen, P., Freychet, P.: Insulin receptors in human circulating cells and fibroblasts. Proc. Natl. Acad. Sci. USA 69, 747-751 (1972)

9. Nakagawa, S., Nakayama, H., Sasaki, T., Yoshino, K., Yu, Y. Y., Shinozaki, K., Aoki, S., Mashimo, K.: A simple method for the determination of serum free insulin levels in insulintreated patients. Diabetes 22, 590-600 (1973)

10. Kurtz, A. B., Matthews, J. A., Nabarro, J. D. N.: Insulin-binding antibody: reaction differences with bovine and porcine insulins. Diabetologia 15, 19-22 (1978)

11. Andersen, O. O., Brunfeldt, K., Abilgard, F.: A method for quantitative determination of insulin antibodies in human plasma. Acta Endocrinol. (Kbh) 69, 195-208 (1972)

12. Heding, L. G., Munkgaard Rasmussen, S.: Human C-peptide in normal and diabetic subjects. Diabetologia 11, 201-206 (1975)

13. Kuzuya, H., Blix, P. M., Horwitz, D. L., Steiner, D. F., Rubenstein, A. H.: Determination of free and total insulin and C-peptide in insulin-treated diabetics. Diabetes 26, 22-29 (1977)

14. Scarlett, J. A., Mako, M. E., Rubenstein, A. H., Blix, P. M., Goldman, J., Horwitz, D. L., Tager, H., Jaspan, J. B., Stjernholm, M. R., Olefsky, J. M.: Diagnosis of factitious hypoglycaemia. N. Engl. J. Med. 297, 1029-1032 (1977)

15. Lowell, F. C.: Evidence for the existence of two antibodies for crystalline insulin. Proc. Soc. Exp. Biol. Med. 50, 167-172 (1942)

16. Berson, S. A., Yalow, R. S.: Species specificity of human antibeef, pork insulin serum. J. Clin. Invest. 38, 2017-2025 (1959)

Received: June 6, 1978, and in revised form: August 14, 1978

Dr. A. B. Kurtz

Department of Nuclear Medicine

The Middlesex Hospital Medical School

London, WIN 8AA, England 